\title{
PENGARUH PENGGUNAAN MEDIA PEMBELAJARAN BERBASIS ICT DAN GAYA BELAJAR TERHADAP HASIL BELAJAR IPA DAN KETERAMPILAN BERTANYA SISWA SD NEGERI 060798 MEDAN AREA
}

\author{
Siti Zahara Harahap ${ }^{1}$, Ulfah Sari Rezeki ${ }^{2)}$ \\ ${ }^{122)}$ Pendidikan Guru Sekolah Dasar Universitas Quality \\ Email : zahraharahap.zh@gmail.com
}

\begin{abstract}
ABSTRAK
Penelitan ini bertujuan untuk mengetahui: (1) Perbedaan hasil belajar siswa yang diajar menggunakan media Camtasia dengan media konvensional; (2) Perbedaan hasil belajar siswa yang memiliki gaya belajar visual, auditori dan kinestetik yang diajar dengan media Camtasia; dan (3) Perbedaan hasil belajar siswa yang memiliki gaya belajar visual, auditori dan kinestetik yang dibelajarkan dengan media Konvensional. Populasi dalam penelitian ini adalah siswa kelas V SD Negeri 060798 Medan Area yang berjumlah 82 siswa yang terdiri dari 3 kelas. Sedangkan sampel penelitian adalah ketiga 3 kelas tersebut. Instrumen penelitian berupa tes hasil belajar IPA, dan angket gaya belajar. Metode penelitian ini bersifat kuasi eksperimen teknik analisis hipotesis uji t; dan analisis varian. Hasil penelitian diperoleh bahwa: (1) Hasil belajar siswa yang dibelajarkan dengan Media Camtasia 85,26 $\pm 5,45$ ( \pm SD) lebih tinggi daripada pembelajaran dengan media konvensional $75,52 \pm 5.86$ ( $\mathrm{t}_{\text {hitung }}=8,147 ; \mathrm{p}=0,000$ ); (2) Terdapat perbedaan hasil belajar siswa yang memiliki gaya belajar visual, auditori dan kinestetik yang dibelajarkan dengan Media Camtasia $\left(\mathrm{F}_{\text {hitung }}=\right.$ 24,964; $\mathrm{p}=0,000$ ); (5) terdapat perbedaan hasil belajar siswa yang memiliki gaya belajar visual, auditori dan kinestetik yang dibelajarkan dengan media Konvensional $\left(F_{\text {hitung }}=6,770 ; p=0,002\right)$.
\end{abstract}

\section{Kata kunci: Media ICT, Gaya Belajar, Hasil Belajar, keterampilan bertanya}

\begin{abstract}
This research aims to find out: (1) Differences in student learning outcomes taught using Camtasia media with conventional media; (2) Differences in student learning outcomes that have visual, auditory and kinesthetic learning styles taught by Camtasia media; and (3) Differences in student learning outcomes that have visual, auditory and kinesthetic learning styles that are learned with conventional media. The population in this study was grade V students of SD Negeri 060798 Medan Area, amounting to 82 students consisting of 3 classes. While the study sample is all 3 classes. The research instrument was in the form of a science learning outcomes test, and a learning style questionnaire. This research method is quasi-experimental hypothesis analysis technique t test; and analysis of variance. The results showed that: (1) Student learning outcomes taught with Media Camtasia $85.26 \pm 5.45( \pm S D)$ were higher than learning with conventional media $75.52 \pm 5.86$ (tcount $=8.147 ; p=0.000$ ); (2) There are differences in student learning outcomes that have visual, auditory and kinesthetic learning styles that are learned with Media Camtasia (Fcount $=24,964 ; p=$ 0,000); (5) there are differences in student learning outcomes that have visual, auditory and kinesthetic learning styles that are learned with Conventional media $(F c o u n t=6.770 ; p=0.002)$.
\end{abstract}

Keywords: ICT Media, Learning Style, Learning Outcomes, questioning skills 


\section{PENDAHULUAN}

Dewasa ini aplikasi media pembelajaran berbasis ICT telah banyak dimanfaatkan dalam penyelenggaraan kegiatan pembelajaran sehingga para pendidik perlu memanfaatkan media dan teknologi pembelajaran guna meningkatkan kualitas pendidikan (Mulyasa, 2007). Agar penggunaan media dan teknologi dapat memberikan kontribusi yang optimal terhadap kualitas hasil belajar siswa, maka penggunaan media dan teknologi harus diintegrasikan dengan kegiatan belajar para siswa. Tidak meragukan lagi, bahwa penggunaan media komputer sangat efektif dalam proses penyampaian informasi dan pemahaman materi pendidikan pada siswa-siswa sekolah (Raharjo, 2007). Selama ini media pembelajaran yang digunakan dalam pembelajaran IPA masih sangat minim, sehingga siswa terkesan kurang aktif dalam kegiatan pembelajaran. Keterbatasan penggunaan media oleh guru selama ini perlu diubah sedikit demi sedikit. Multimedia berbasis komputer adalah salah satu media yang mengkombinasikan antara teks, grafis, animasi, suara, dan video (Arsyad, 2007).

Menurut Brets dalam Sanjaya (2008) terdapat tujuh klasifikasi media pembelajaran, yaitu; (1) media audio visual dan gerak; (2) media audio visual diam; (3) media audio semi gerak; (4) media visual gerak; (5) media visual diam; (6) media audio;dan (7) media cetak. Sedangkan ditinjau dari sudut kemuktahiran pemakaiannya media pembelajaran dibagi dalam 2 (dua) jenis, yaitu: media pembelajaran sederhana dan media pembelajaran modern (Munir, 2008). Media pembelajaran sederhana meliputi papan tulis, buku, sedangkan media pemeblajaran modern meliputi komputer dan internet.

Rahardjo (2007) menyatakan bahwa media dalam arti yang terbatas, yaitu sebagai alat bantu pembelajaran. Hal ini berarti media sebagai alat bantu yang digunakan untuk: (1) memotivasi belajar peserta didik; (2) memperjelas informasi/papan pembelajaran; (3) memberi tekanan pada bagian-bagian yang penting; (4) memberi variasi pembelajaran; dan (5) memperjelas struktur pembelajaran.

Media pembelajaran sebagai media antara guru sebagai pengirim informasi dan penerima informasi harus komunikatif, khususnya untuk obyek secara visualisasi. Dalam pembelajaran ilmu pengetahuan alam, khusunya konsep yang berkaitan dengan alam semesta lebih banyak menonjol visualnya, sehingga apabila seseorang hanya mengetahui kata yang mewakili suatu obyek, tetapi tidak mengetahui obyeknya disebut verbalisme. Masing-masing media mempunyai keistimewaan menurut karakteristik siswa. Pemilihan media yang sesuai dengan karakteristik siswa akan lebih membantu keberhasilan pengajar dalam pembelajaran. Secara rinci fungsi media memungkinkan siswa menyaksikan obyek yang ada tetapi sulit untuk dilihat dengan kasat mata melalui perantaraan gambar, potret, slide, dan sejenisnya yang mengakibatkan siswa memperoleh gambaran yang nyata (Laria, 2008).

Fungsi utama media pembelajaran adalah sebagai alat bantu mengajar yang turut mempengaruhi iklim, kondisi, dan lingkungan yang ditata serta diciptakan oleh guru (Arysad, 2007). Sehingga media pembelajaran dapat mempertinggi proses belajar siswa dalam pembelajaran yang pada gilirannya diharapkan dapat mempertinggi proses belajar siswa (Sudjana \& Rivai, 2002). Sehingga dalam proses pembelajaran, media memiliki fungsi sebagai pembawa informasi dari sumber (guru) menuju penerima (siswa). Sedangkan metode adalah prosedur untuk membantu siswa dalam menerima dan mengolah informasi guna mencapai tujuan pembelajaran.

Keterlibatan siswa dalam kegiatan belajar mengajar sangat penting, karena seperti yang dikemukakan oleh Dale (Heinich, et.al., 2002) dalam klasifikasi pengalaman menurut tingkat dari yang paling konkrit ke yang paling abstrak, dimana partisipasi, observasi, dan pengalaman langsung memberikan pengaruh yang sangat besar terhadap pengalaman belajar yang diterima siswa. Penyampaian suatu konsep pada siswa akan tersampaikan dengan baik jika konsep tersebut mengharuskan siswa terlibat langsung didalamnya bila dibandingkan dengan konsep yang hanya melibatkan siswa untuk mengamati saja. Berdasarkan penjelasan diatas, maka dengan penggunaan media pembelajaran diharapkan dapat memberikan pengalaman belajar yang lebih konkret kepada siswa, dan dapat meningkatkan keaktifan siswa dalam pembelajaran. (Laria, 2008).

Pada prinsipnya media pembelajaran diarahkan untuk memudahkan siswa belajar dalam upaya memahami materi pelajaran. Secara prosedural pemilihan dan penggunaan 
media pembalajaran harus dipandang dari sudut kebutuhan siswa. Dalam hal ini Sanjaya (2008) mengemukakan prinsip-prinsip dalam pemilihan media pembelajaran, di antaranya: (1) pemilihan media harus sesuai dengan tujuan yang ingin dicapai. Apakah tujuan tersebut bersifat kognitif, afektif, atau psikomotorik. Setiap media memiliki karakteristik, sehingga harus dipertimbangkan dalam pemakaiannya. Pemilihan media harus berdasarkan konsep yang jelas. Artinya pemilihan media tertentu bukan didasarkan kepentingan guru atau sekedar keselingan, melainkan harus menjadi bagian integral dalam keseluruhan proses pembelajaran dalam upaya meningkatkan efektivitas dan efisiensi pembelajaran siswa; (2) pemilihan media harus disesuaikan dengan karakteristik siswa. Ada media yang cocok untuk kelompok siswa, namun tidak cocok untuk siswa yang lain; dan (3) pemilihan media harus sesuai dengan kondisi lingkungan, fasilitas dan waktu yang tersedia untuk kebutuhan pembelajaran.

Keberhasilan pembelajaran selain dipengaruhi oleh tidak tepatnya pemilihan media pembelajaran dan keterampilan guru dalam penggunaannya mungkin juga disebabkan faktor gaya belajar siswa yang berbeda-beda. Gaya belajar seseorang adalah kombinasi dari bagaimana ia menyerap, dan kemudian mengatur serta mengolah informasi (DePorter \& Henarcki, 2003). Gaya belajar merupakan salah satu faktor penting dalam meningkatkan prestasi belajar serta kualitas pendidikan. Hasil penelitian Panggabean (2009) terhadap prestasi belajar berdasarkan tipe belajar mahasiswa menunjukkan bahwa prestasi belajar sangat memuaskan memiliki kecenderungan pada tipe belajar visual $(72,5 \%)$, auditori $(65,7 \%)$, kinestetik (50\%), dan visual-auditori (60\%).

\section{METODE PENELITIAN}

Penelitian ini menggunakan metode quasi eksperimen. Penelitian ini dilaksanakan di SD Negeri 060798 Medan Area. Populasi dalam penelitian ini adalah siswa kelas V SD Negeri 060798 Medan Area yang berjumlah 82 siswa yang terbagi ke dalam 3 kelas yaitu kelas V/a, V/b dan V/c. Adapun sampel yang digunakan adalah ketiga kelas tersebut. Kelas pertama belajar dengan menggunakan media Camtasia, kelas kedua belajar dengan menggunakan media powerpoint, dan kelas ketiga merupakan kelas kontrol dengan menggunakan media konvensional. Teknik pengumpulan data dalam penelitian ini adalah angket gaya belajar dan tes hasil belajar. Uji prasyarat diantaranya uji normalitas dilakukan dengan Kolmogorov Smirnov dan uji homogenitas dilakukan dengan Levene's test. Pengujian hipotesis dalam penelitian ini terbagi atas 2 bagian, yakni: (1) untuk melihat hasil belajar yang lebih baik dilakukan dilakukan dengan menggunakan uji t; (2) untuk melihat perbedaan hasil belajar siswa dilakukan dengan menggunakan ANAVA satu arah.

\section{HASIL DAN PEMBAHASAN}

Berdasarkan data penelitian yang telah didapatkan kemudian selanjutnya dilakukan analisis hasil penelitian, berikut distribusi frekuensi hasil analisis penelitian.

\section{a) Deskripsi Data Penelitian}

\section{Post Test Hasil Belajar Siswa}

Deskripsi hasil belajar siswa yang dibelajarkan dengan media Camtasia dengan $\mathrm{N}$ $=38$ siswa diperoleh nilai rata-rata hasil belajar siswa sebesar $=85,26$ dengan nilai minimum $=76,67$; nilai maksimum $=96,67$; standard deviasi $=5,45$; dan; standard error $=$ 0,88 . Deskripsi hasil belajar siswa yang dibelajarkan dengan media Power Point dengan $\mathrm{N}=38$ siswa diperoleh nilai rata-rata hasil belajar siswa sebesar $=83,15$ dengan nilai minimum $=70,00$; nilai maksimum $=$ 93,33; standard deviasi $=6,84$; dan; standard error $=1,10$. Deskripsi hasil belajar siswa yang dibelajarkan dengan pembelajaran konvensional dengan $\mathrm{N}=38$ siswa diperoleh nilai rata-rata hasil belajar siswa sebesar $=$ 75,52 dengan nilai minimum $=56,67$; nilai maksimum $=86,67$; standard deviasi $=5,86$; dan; standard error $=0,95$. Deskripsi hasil belajar siswa dapat disajikan pada gambar berikut: 


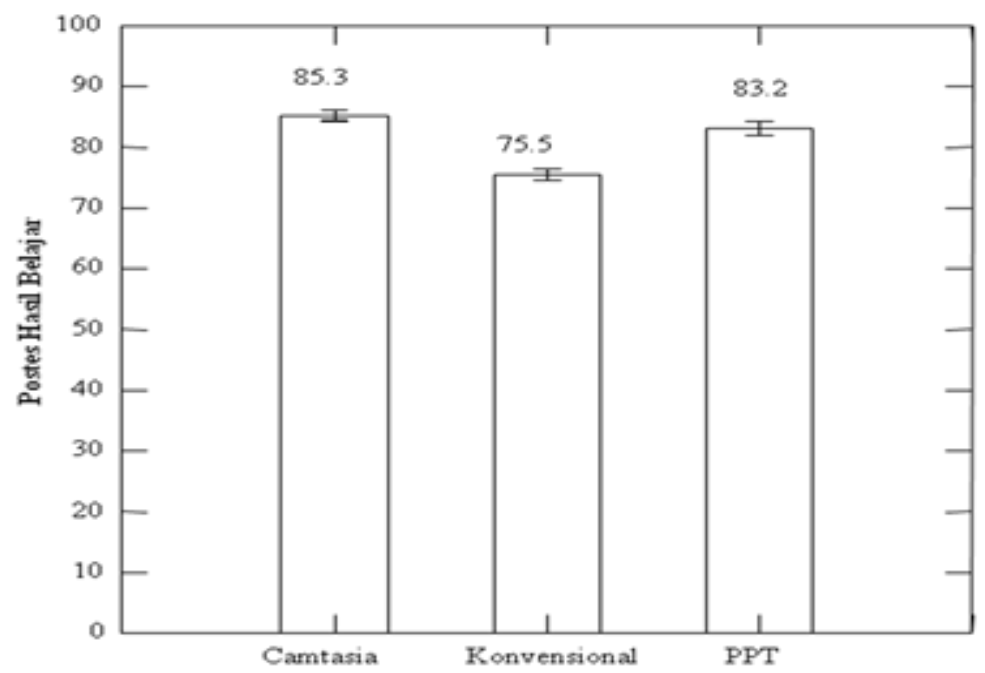

Gambar 1 Hasil Post test Siswa pada Masing-masing Media Pembelajaran

\section{Pre-Test dan Post-Test Hasil Belajar} Siswa dengan Media Camtasia

Deskripsi pretes siswa yang dibelajarkan dengan media Camtasia diperoleh nilai rata-rata pretes siswa pada: (1) gaya belajar visual sebesar $=43,33$ dengan standard deviasi $=11,44 ;(2)$ gaya belajar auditori sebesar $=43,20$ dengan standard deviasi $=$ 8,14 ; dan (3) gaya belajar kinestetik sebesar $=$ 46,67 dengan standard deviasi $=14,14$.
Deskripsi post test siswa yang dibelajarkan dengan media Camtasia diperoleh nilai ratarata siswa pada: (1) gaya belajar visual sebesar $=86,00$ dengan standard deviasi $=5,43 ;(2)$ gaya belajar auditori sebesar $=85,13$ dengan standard deviasi $=8,14$; dan (3) gaya belajar kinestetik sebesar $=83,34$ dengan standard deviasi $=4,72$. Berikut grafik pretes dan post test siswa yang dibelajarkan dengan media Camtasia.

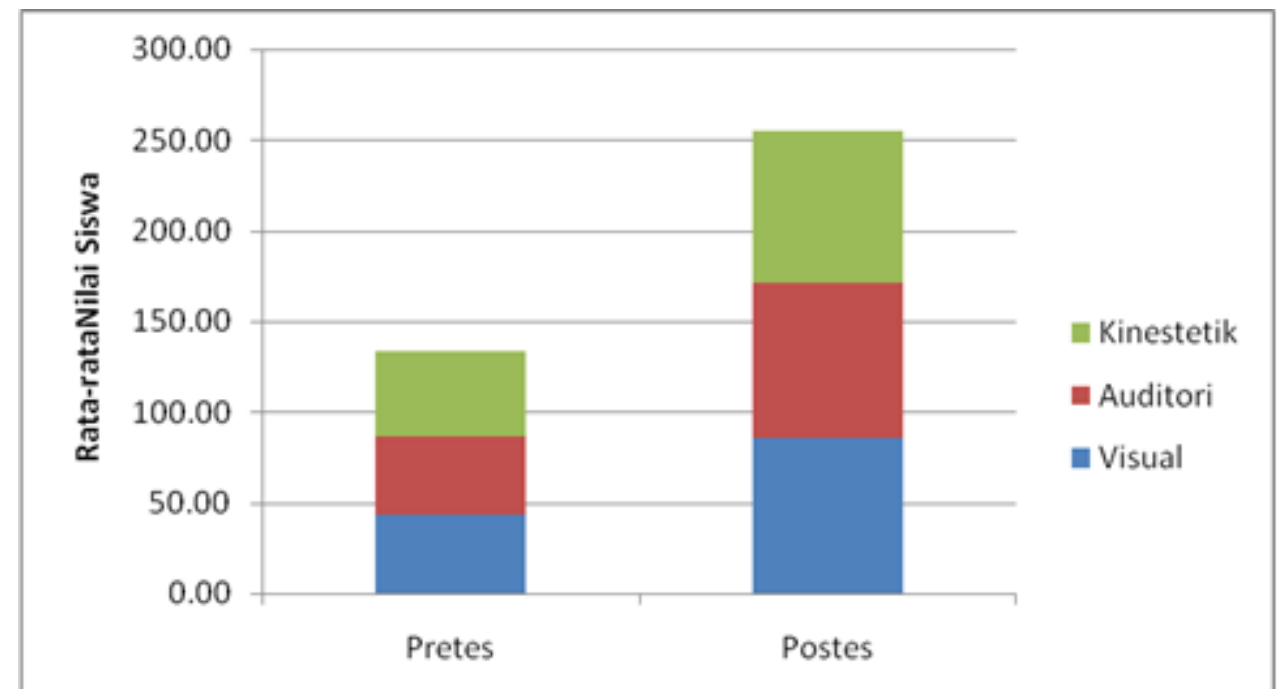

Gambar 2 Hasil Belajar Siswa dengan Media Camtasia

\section{Pre-Test dan Post-Test Hasil Belajar Siswa dengan Media Powerpoint}

Deskripsi pretes siswa yang dibelajarkan dengan media powerpoint diperoleh nilai rata-rata pretes siswa pada: (1) gaya belajar visual sebesar $=40,83$ dengan standard deviasi $=5,56$; (2) gaya belajar auditori sebesar $=42,86$ dengan standard deviasi $=8,65$; dan (3) gaya belajar kinestetik sebesar $=47,74$ dengan standard deviasi $=$ 11,42 .

Deskripsi hasil belajar siswa yang dibelajarkan dengan media power point diperoleh nilai rata-rata siswa pada: (1) gaya belajar visual sebesar $=82,50$ dengan standard deviasi $=6,61 ;(2)$ gaya belajar auditori 
sebesar $=84,13$ dengan standard deviasi $=$ 6,98; dan (3) gaya belajar kinestetik sebesar $=$ 81,48 dengan standard deviasi $=7,09$. Berikut grafik pretes dan post test siswa yang dibelajarkan dengan media powerpoint.

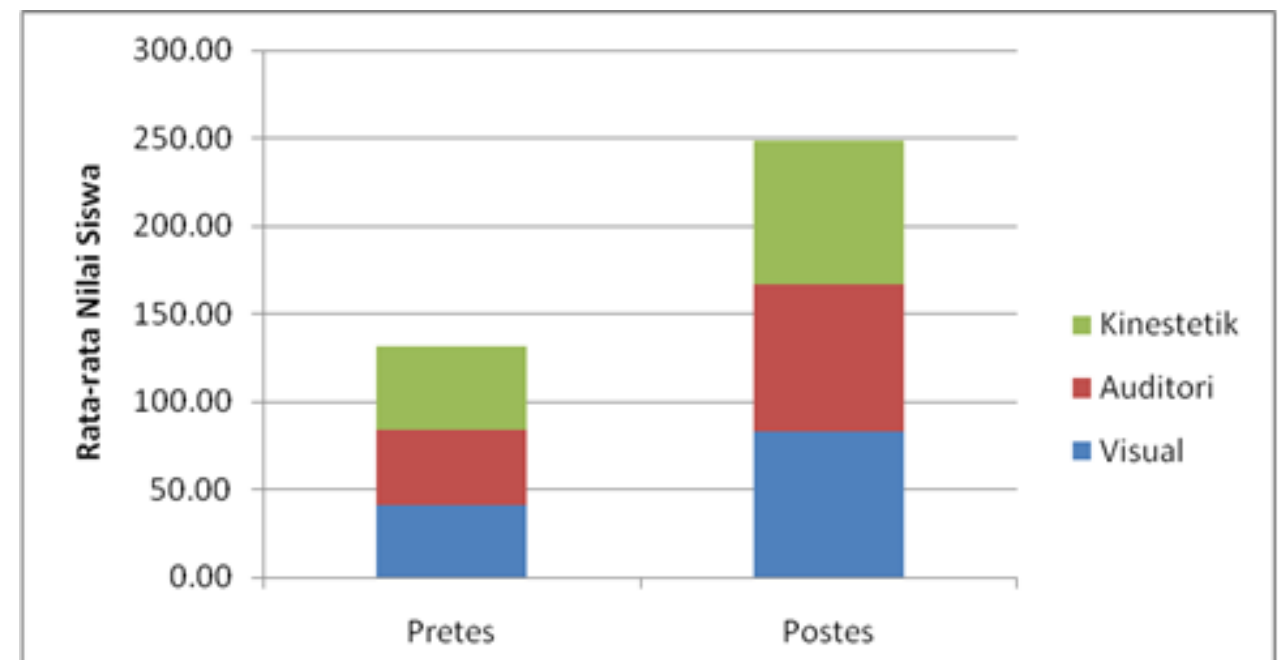

Gambar 3 Hasil Belajar Siswa dengan Media Powerpoint

\begin{abstract}
4. Pre-Test dan Post-Test Hasil Belajar Siswa dengan Media Konvensional

Deskripsi pretes siswa yang dibelajarkan dengan pembelajaran konvensional diperoleh nilai rata-rata pretes siswa pada: (1) gaya belajar visual sebesar $=$ 46,11 dengan standard deviasi $=2,51$; (2) gaya belajar auditori sebesar $=44,37$ dengan standard deviasi $=9,78$; dan (3) gaya belajar kinestetik sebesar $=0,00$.
\end{abstract}

Deskripsi hasil belajar siswa yang dibelajarkan dengan pembelajaran konvensional diperoleh nilai rata-rata siswa pada: (1) gaya belajar visual sebesar $=75,00$ dengan standard deviasi $=2,79 ;$ (2) gaya belajar auditori sebesar $=75,63$ dengan standard deviasi $=6,30$; dan (3) gaya belajar kinestetik sebesar $=0,00$. Berikut grafik pretes dan post test siswa yang dibelajarkan dengan media powerpoint.

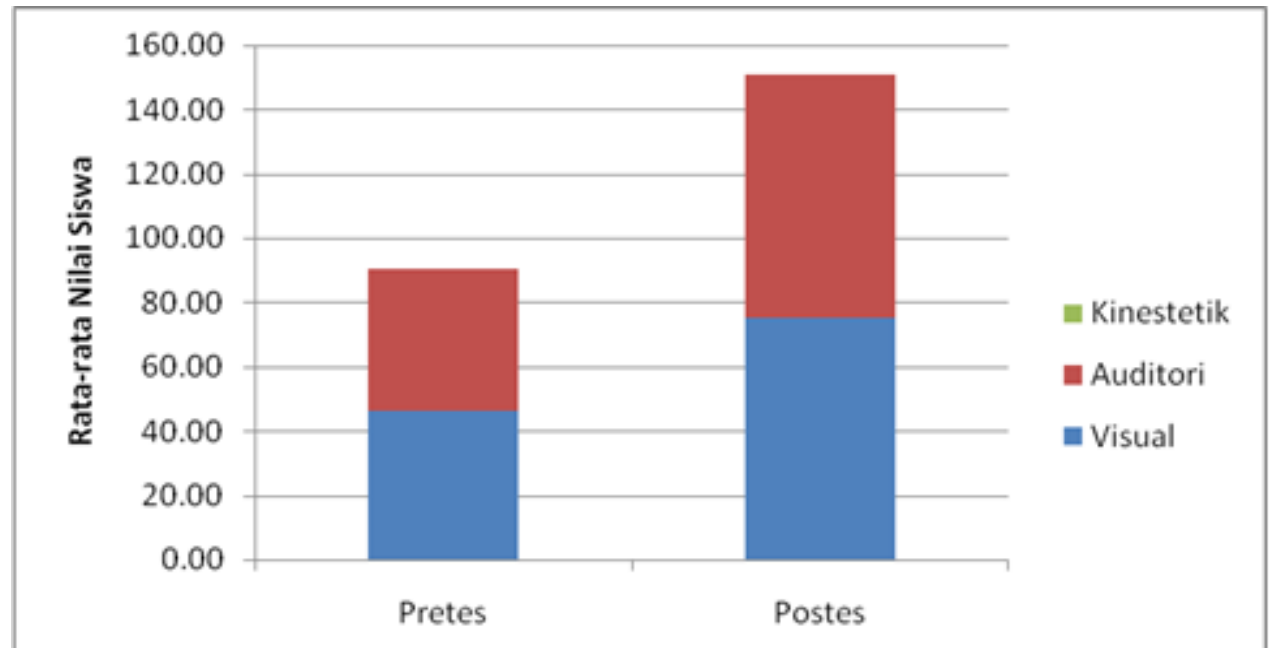

Gambar 4 Hasil Belajar Siswa dengan Media Konvensional

b) Pengujian Hipotesis

1. Perbandingan Hasil Belajar Siswa Menggunakan Media Camtasia dengan Hasil Belajar Siswa Menggunakan Powerpoint

Berdasarkan hasil uji hipotesis diperoleh bahwa hasil belajar siswa yang 
dibelajarkan dengan Media Camtasia 85,26 \pm 5,45 ( $\bar{X} \pm \mathrm{SD}$ ) tidak lebih tinggi daripada yang dibelajarkan dengan Power Point 83,15 \pm 6,84 pada materi keanekaragaman makhluk hidup kelas VII di SMP Negeri 1 Tanjungmorawa $\left(\mathrm{t}_{\text {hitung }}=1,384 ; \mathrm{p}=0,175\right)$.

\section{Perbandingan Hasil Belajar Siswa Menggunakan Media Camtasia dengan Hasil Belajar Siswa Menggunakan Konvensional \\ Berdasarkan hasil uji hipotesis} diperoleh bahwa hasil belajar siswa yang dibelajarkan dengan Media Camtasia 85,26 \pm $5,45$ ( $\bar{X} \pm \mathrm{SD})$ lebih tinggi daripada pembelajaran dengan media konvensional 75,52 \pm 5.86 pada materi keanekaragaman makhluk hidup kelas VII di SMP Negeri 1 Tanjungmorawa $\left(\mathrm{t}_{\text {hitung }}=8,147 ; \mathrm{p}=0,000\right)$.

\section{Perbandingan Hasil Belajar Siswa Menggunakan Media Powerpoint dengan Hasil Belajar Siswa Menggunakan Konvensional \\ Berdasarkan hasil uji hipotesis} diperoleh bahwa hasil belajar siswa yang dibelajarkan dengan Power Point 83,15 \pm 6,84 ( $\bar{X} \pm \mathrm{SD}$ ) lebih tinggi daripada pembelajaran dengan media konvensional 75,52 \pm 5,86 pada materi keanekaragaman makhluk hidup kelas VII di SMP Negeri 1 Tanjungmorawa ( $t_{\text {hitung }}=$ $5,208 ; p=0,000)$.

\section{Perbedaan Hasil Belajar Siswa yang Memiliki Gaya Belajar Visual, Auditori dan Kinestetik yang Diajar dengan Media Camtasia \\ Berdasarkan hasil uji hipotesis} diperoleh bahwa terdapat perbedaan hasil belajar tentang keanekaragaman mahluk hidup siswa yang memiliki gaya belajar visual, auditori dan kinestetik yang dibelajarkan dengan Media Camtasia di kelas VII SMP Negeri 1 Tanjungmorawa $\left(F_{\text {hitung }}=24,964 ; p=\right.$ $0,000)$.

5. Perbedaan Hasil Belajar Siswa yang Memiliki Gaya Belajar Visual, Auditori dan Kinestetik yang Diajar dengan Media Powerpoint

Berdasarkan hasil uji hipotesis diperoleh bahwa terdapat perbedaan hasil belajar tentang keanekaragaman mahluk hidup siswa yang memiliki gaya belajar visual, auditori dan kinestetik yang dibelajarkan dengan Media Power Point di kelas VII SMP Negeri 1 Tanjungmorawa $\left(F_{\text {hitung }}=6,770 ; p=\right.$ $0,002)$.

\section{Hubungan antara Gaya Belajar dengan Hasil Belajar Siswa \\ Berdasarkan hasil uji hipotesis} diperoleh bahwa tidak terdapat hubungan antara gaya belajar dengan hasil belajar siswa tentang keanekaragaman mahluk hidup di kelas VII SMP Negeri 1 Tanjungmorawa $(\mathrm{p}=$ $0,802)$.

Media pembelajaran merupakan saran yang dapat membantu guru dalam menyampaikan materi pembelajaran di depan kelas. Sebagaimana dikemukakan oleh Smaldino (2008) bahwa media pembelajaran merupakan penghubung antara pembawa informasi dengan penerima pesan. Dimana pembawa informasi yang dimaksud merupakan guru yang menghubungkan materi pembelajaran yang akan disampaikan kepada penerima pesan, yakni siswa itu sendiri. Pada hasil penelitian ini diperoleh hasil berupa terdapat pengaruh penggunaan media pembelajaran berbasis ICT terhadap hasil belajar siswa. Hal ini dapat dilihat dari ratarata hasil belajar siswa yang diperoleh, yakni: (1) hasil belajar siswa yang dibelajarkan dengan Media Camtasia 85,26 $\pm 5,45(\bar{X} \pm$ SD); (2) hasil belajar siswa yang dibelajarkan dengan Power Point 83,15 \pm 6,84; dan (3) pembelajaran dengan media konvensional diperoleh 75,52 $\pm 5,86$.

Berdasarkan rata-rata belajar siswa tersebut, media merupakan sarana yang baik dan tepat dalam meningkatkan hasil belajar siswa, khususnya pada mata pelajaran IPA, materi keanekaragaman makhluk hidup. Penggunaan media pembelajaran berbasis ICT ini membawa materi keanekaragaman makhluk hidup agar mudah dipahami maksud dari isi materi pelajaran tersebut. Hal ini disampaikan pula menurut Arsyad (2007), media pembelajaran adalah media yang membawa pesan-pesan atau informasi yang bertujuan intruksional atau mengandung maksud-maksud pembelajaran.

\section{KESIMPULAN}

Berdasarkan hasil penelitian dan analisis data, maka dapat ditarik kesimpulan sebagai berikut: 
1. Hasil belajar siswa yang diajar dengan media Camtasia tidak lebih tinggi daripada hasil belajar siswa yang diajar dengan media Powerpoint $\left(\mathrm{t}_{\text {hitung }}=1,384 ; \mathrm{p}=0,175\right)$.

2. Hasil belajar siswa yang diajar dengan media Camtasia tidak lebih tinggi daripada hasil belajar siswa yang diajar dengan media konvensional $\left(\mathrm{t}_{\text {hitung }}=8,147 ; \mathrm{p}=\right.$ $0,000)$.

3. Hasil belajar siswa yang diajar dengan media Powerpoint tidak lebih tinggi daripada hasil belajar siswa yang diajar dengan media konvensional $\left(\mathrm{t}_{\text {hitung }}=5,208 ; \mathrm{p}=\right.$ 0,000 ).

4. Terdapat perbedaan hasil belajar siswa yang memiliki gaya belajar visual, auditori dan kinestetik yang diajar dengan Media Camtasia $\left(\mathrm{F}_{\text {hitung }}=\right.$ 24,964; $\mathrm{p}=0,000$ ).

5. Terdapat perbedaan hasil belajar siswa yang memiliki gaya belajar visual, auditori dan kinestetik yang diajar dengan Media Powerpoint $\left(\mathrm{F}_{\text {hitung }}=\right.$ 6,770; $\mathrm{p}=0,002$ ).

6. Tidak terdapat hubungan antara gaya belajar dengan hasil belajar siswa $(\mathrm{p}=$ $0,802)$.

\section{DAFTAR PUSTAKA}

Arsyad, A. 2012. Media Pembelajaran. Jakarta: Raja Grafindo Persada.
DePorter dan Hernacki. 2002. Quantum Learning. Bandung: Kaifa.

Heinich, R., Molenda, M., Russell, J, D., dan Smaldino, S, E. 2002. Instructional Media and Technology for Learning, 7th edition. New Jersey: Prentice Hall, Inc.

Laria, K. 2008. Kajian Pustaka Media Pembelajaran.

(http://www.infoskripsi.com, diakses 13 Juni 2019).

Mulyasa. 2013. Kurikulum Tingkat Satuan Pendidikan. Bandung: Remaja Rosdakarya.

Raharjo. 2007. Multimedia dalam Pembelajaran. Jakarta. http://www.diknas.lipi.go.id (diakses tanggal 13 Juni 2019)

Sanjaya, F. 2011. Pengaruh Penggunaan CD Multimedia Interaktif Quiz Creator untuk Meningkatkan Hasil Belajar Siswa Kelas XI Rekayasa Perangkat Lunak pada Pelajaran Desain Web di SMKN 4 Tanjung Balai. Medan: FT Unimed.

Smaldino, S, E., dan Deborah, L. L. 2014 . Instructional Technology \& Media for Learning: Teknologi Pembelajaran dan Media untuk Belajar. Jakarta: Prenada Media Group.

Sudjana, N., dan Rivai, A. 2012. Media Pengajaran. Bandung: Sinar Baru Algensindo. 